\title{
Analysis of The Motivation of Coffee Farmers in Applying Good Agriculture Practices in Arabic Coffee Commodities in South Tapanuli District
}

\author{
Yuliana Kansrini ${ }^{1}$, Dwi Febrimeli ${ }^{2}$, Puji Wahyu Mulyani ${ }^{3}$ \\ 1,2,3 Program Studi Penyuluhan Perkebunan Presisi, Jurusan Perkebunan, Politeknik Pembangunan Pertanian Medan, \\ Jl. Binjai Km. 10 Tromol Pos 18, 2002, Medan, Sumatera Utara, Indonesia. \\ 1'yulianakansrini67@gmail
}

\begin{abstract}
The implementation of Good Agriculture Practices in the Arabica coffee plants by the farmers in the South Tapanuli Regency is an effort to solve technical problems to increase the production and competitiveness of these commodities. Therefore, the farmers need to improve their knowledge and skills in optimizing the productivity of the commodity they manage. The objective of this study is to determine the motivation level of the farmers in implementing good agriculture practice, to analyze the factors that influence the motivation of the farmers in implementing good agriculture of coffee in the South Tapanuli Regency. This research is quantitative with analytical descriptive. The basis for selecting the research location was the purposive method. The sample was determined by a purposive sampling method that was following the criteria in this study, namely 60 coffee farmers. The data collection technique was done by filling out questionnaires and in-depth interviews. Data analysis was performed by tabulating quantitative data with scoring results and multiple linear regression analysis. The results obtained in this study show that the level of motivation of farmers in good cultivation of Arabica coffee in South Tapanuli Regency is in the high category (51.66 percent). The factors that influence the level of motivation of coffee farmers in implementing good cultivation of Arabica coffee are age, experience, and nature of innovation. Meanwhile, education, income, and land area have a no-significant effect on the motivation level of the farmers in implementing good cultivation of Arabica coffee.
\end{abstract}

Keywords

Efficiendi eum; Apeirian; Omnium; Doctus quaestio congue

Article Received: 10 August 2020, Revised: 25 October 2020, Accepted: 18 November 2020

\section{Introduction}

Indonesia is one of the largest Arabica coffee producing countries in the world after Brazil, Vietnam, and Colombia with a total production of 675,882 tons/year. The achievement of coffee exports grew by 1.34 percent from 2019. Some of the biggest export destination countries since 2019 include the Philippines, the United States, Malaysia, Italy, and Japan. Indonesian coffee is famous for its speciality coffee or also known as geographically indicated coffee so that world coffee lovers say that Indonesia is a world coffee paradise with 39 types of the best speciality coffee variants. Speciality coffee is coffee with good quality. On the other hand, the majority of Indonesians are less educated about speciality coffee (Ratnasari, 2018)

Currently, coffee business opportunities are increasingly open, in line with the level of coffee consumption in Indonesia in the 2016-2021 period, which is predicted to grow an average of 8.22 percent/year. The development of the number of coffee business outlets in Indonesia has also increased to 2,973 outlets in 2019. Each coffee-producing region has a distinctive coffee taste by the unique soil and air conditions. The coffee flavours and quality of the exported coffee are in great demand and recognized by the international market. North Sumatra as one of the Arabica coffee producers in Indonesia. Arabica coffee is suitable to be grown in North Sumatra which has many mountainous areas. Because Arabica coffee can only be grown at an altitude of 600-2,000 meters above sea level and cold. Arabica coffee also requires adequate moisture, fertile soil, and sunshine. Currently, North Sumatra is the third-largest producer of arabica coffee in Indonesia, namely 49,176.51 tonnes/year or 32.05 percent, and is one of the largest exporters of Arabica coffee, amounting to 105,137 tonnes/year.

The Planting area for Arabica coffee in North Sumatra reaches $61,231.44$ hectares with a production of $49,176.51$ tons. Arabica coffee is spread in the highlands such as North Tapanuli, South Tapanuli, Toba Samosir, Simalungun, Mandailing Natal, Dairi, West Pakpak, and Humbang Hasundutan districts. Also, robusta coffee is being developed. The planted area reaches 21,663.81 hectares with a total production of 9,663.52 tons. Robusta coffee types are scattered in South Tapanuli and Deli Serdang Regencies (disbun.sumutprov.go.id).

The following describes the land area and the amount of coffee plants production as well as its geographical indication in North Sumatra as presented in the following table:

Tabel 1. Land Area and Total Production of Arabica Coffee Commodities in North Sumatra in 2019

\begin{tabular}{ccc}
\hline Regency & Land Area (ha) & Total Production (ton) \\
\hline Tapanuli Utara & $14,485,06$ & $13,923,522$ \\
Dairi & $11,382,00$ & $8,409,00$ \\
Humbang Hasundutan & $11,374,50$ & $6,807,10$ \\
Karo & $8,378,44$ & $6,877,02$ \\
Simalungun & $7,843,48$ & $9,743,50$ \\
Samosir & $4,913,24$ & $3,866,35$ \\
Toba Samosir & $4,076,36$ & $3,741,00$ \\
Tapanuli Selatan & $3,310,40$ & $1,073,86$ \\
Mandailing Natal & $2,907,85$ & $2,154,31$ \\
Total & $68,671,33$ & $56,595,662$
\end{tabular}

(Source: disbun.sumutprov.go.id, 2020)

Based on Table 1, it is known that those with the potential for developing Arabica coffee plants Agriculture Practices have the largest area of 14.485.06 hectares and the highest production is 13,923,552 tons, namely North Tapanuli 
Regency. Mandailing Natal Regency is included in the small land category of $2,907.85$ hectares with a production of $2,154.31$ tons. It is different from South Tapanuli Regency which has a wider area than Mandailing Natal Regency, but the production yield is the lowest. Meanwhile, the potential for market demand is increasing for both the national and international markets. Therefore, it is necessary to increase the productivity of the coffee commodity in South Tapanuli Regency through the support of innovation and technology that is useful for coffee producer farmers in managing their coffee plantation businesses. As the government implements an export policy in the form of ISCOffee and policies regarding post-harvest technology which are written in the Regulation of the Minister of Agriculture of the Republic of Indonesia number 52 / Permentan / OT.140 / 9/2012 regarding post-harvest technology (disbun.sumutprov.go.id). Based on information through the 2019 North Sumatra Province Plantation Service document, it states that there are technical problems in efforts to increase production and competitiveness of coffee commodities. For coffee production to also increase, coffee producer farmers need to improve their knowledge and skills in optimizing the productivity of the coffee commodity they manage. According to Sudarko (2012), a relevant strategy in efforts to increase coffee plant productivity is one of them through the application of innovations per local peculiarities, this is related to economic efficiency and optimization in the use of agricultural production inputs.

One effort that can be done is to introduce farmers to the Agriculture Practices of coffee commodities following Good Agricultural Practices. The implementation of Good Agriculture Practices in the correct Arabica coffee plants can increase production achievements, the quality of the products produced, market demand, the sustainability of farming improves the welfare of coffee farmers, and can realize an increase in regional economic income. According to Rudiantho (2017), an increase in Arabica coffee production can be achieved with an intensification strategy through optimizing land use and family labour used as well as implementing good Agriculture Practices of commodities in which there is a planting of shade trees by the number of main commodities, fertilization with organic systems, pruning unproductive branches, conserving land and controlling pests. However, it is also necessary to pay attention to the socio-economic and ecological conditions faced by farmers to promote sustainable growth that is towards standards oriented

Coffee farmers in South Tapanuli Regency have been acquiring knowledge about good coffee commodity Agriculture Practices through direct counselling activities in regular farmer group meetings and participating in the Integrated Pest Management farmer field school (SL-PHT). However, based on conditions in the field, there are still many farmers who have not implemented good agriculture practice of the Arabica coffee commodity in their field management. Therefore, how coffee farmers apply good agriculture practice to their coffee commodity needs to be studied so that it can be gaining information and input to increase the production of Arabica coffee commodity in the South Tapanuli Regency.

This study aims to; (1) Knowing the motivation of coffee farmers in implementing good agriculture practice of coffee in the South Tapanuli Regency, (2) Analyzing the factors that influence the motivation of coffee farmers in implementing good agriculture of coffee in South Tapanuli Regency.

\section{Methods}

This type of research is quantitative with analytical descriptive. This research has been conducted for 8 months, between April - November 2019 in South Tapanuli Regency. The basis for selecting the research location was the purposive method. The research sample was chosen deliberately, namely coffee farmers who are members of farmer groups who have received coffee seed assistance and participated in counselling activities on good Agriculture Practices of Arabica coffee by Field Extension Worker (PPL), namely 60 coffee farmers as research samples from Sipirok District, East Angkola District, Arse District, Marancar District, and Saipar Dolok Hole District, South Tapanuli Regency.

Data and information collection methods are carried out by:

(1) documentation, which is used to obtain secondary data,

(2) observation, which is the condition of the area and farmer activities; (3) The questionnaire regarding farmer motivations as well as factors that are thought to influence farmer motivations. The method of data analysis through the validity test stage of the measuring instrument refers to the degree of function of measuring a test or the degree of accuracy of the measurement of a test or the extent to which the test measures what is intended to be measured. In the validity test, the Pearson Product Moment correlation formula can be used. The reliability of measuring instruments shows the extent to which the results of measurements with these tools can be trusted. For reliability testing, the Cronbach Alpha method was used. The higher the reliability coefficient value, the more reliable the measurement (Azwar, 2010).

Hypothesis testing objective is 1 , the measurement of motivation is done through cross-tabulation. To test the hypothesis of objective 2 , the analysis of the factors that influence the motivation of coffee farmers, frequency analysis is used with the STATA version 13 program. To determine the influence of each internal and external factor on farmer motivation using multiple regression statistical analysis. Multiple regression is a regression technique when there is more than one variable to predict the dependent variable. The formula used is: $\mathrm{Y}=\alpha+\beta 1 \mathrm{X} 1+\beta 2 \mathrm{X} 2+\beta 3$ $\mathrm{X} 3+\beta 4 \mathrm{X} 4+\beta 5 \mathrm{X} 5$. With details that, $\mathrm{Y}=$ level of motivation of farmers, $\alpha=$ constant, $\beta=$ regression coefficient, $\mathrm{X} 1$ = age, $\mathrm{X} 2$ = education, $\mathrm{X} 3$ = income, $\mathrm{X} 4$ = experience, $\mathrm{X} 5=$ land area, $\mathrm{X} 6=$ nature of innovation.

\section{Results and Discussion}

South Tapanuli Regency (Kabupaten Tapanuli Selatan) with its natural geographical conditions, has the potential for natural resources in the agricultural, horticultural, plantation, livestock, and fishery sectors. Alongside Salacca (snake fruit) commodity, currently coffee is an idol among the farming community. Data on the distribution of planting area and production of Arabica coffee commodities by the district is shown in the following table. 
Table 2. Area of Commodity and Commodity Production of Arabica Coffee by District, 2019
Table 3. Motivation Levels of Farmers in Implementing Good Agriculture Practice of Arabica Coffee on Existence

\begin{tabular}{lcc}
\hline \multicolumn{1}{c}{ District(Kecamatan) } & TBM & $\begin{array}{c}\text { Area of Co } \\
\text { TM }\end{array}$ \\
\hline Batang Angkola & 11,00 & 11,00 \\
Sayur Matinggi & - & - \\
Tano Tombangan Angkola & - & - \\
Angkola Timur & 13,40 & 52,50 \\
Angkola Selatan & 6,50 & 17,50 \\
Angkola Barat & 2,00 & 0,50 \\
Angkola Sangkunur & 2,50 & 0,50 \\
Batang Toru & 2,50 & 1,50 \\
Marancar & 62,00 & 131,00 \\
Muara Batang Toru & 1,00 & - \\
Sipirok & 285,00 & 219,00 \\
Arse & 43,00 & 29,00 \\
Saipar Dolok Hole & 813,00 & 202,00 \\
Aek Bilah & 19,00 & 99,00 \\
Total & $1.260,90$ & 763,50
\end{tabular}

Source: BPS, Tapsel in numbers, 2019

South Tapanuli Regency has 14 districts, consisting of 212 villages and 26 sub-districts. The types of coffee that have been developed in the South Tapanuli Regency are Arabica coffee and Robusta coffee. For its development, adjusting the growing requirements for the two types of coffee. Under climatic and geographic conditions, obtained recommendations to develop Arabica coffee in 5 (five) districts that are meet the requirements for growing Arabica coffee, namely 800-1,200 above sea level (asl).

The motivation theory used in this study is Existence, Relatedness, Growth (ERG). This theory was developed by Clayton Alderfer. The ERG theory states that a person's needs can be simplified into three categories of needs that do not occur hierarchically in practice, namely: (1) existence needs, the need to maintain one existence in life. This need will be satisfied by factors such as food, drink, air, salary, working conditions; (2) relatedness needs, the need to interact with other people, which is fulfilled by the existence of meaningful social and interpersonal relationships; (3) growth needs, the need to develop oneself which can be met by creating creative and productive contributions from a person to the group.

The results of research on the distribution of coffee farmers' motivation in implementing Good Agriculture Practices of coffee in the South Tapanuli Regency can be seen in Table 4. The components of motivation are divided into three, namely self-recognition (existence), relationship (relatedness), and self-development (growth). These three aspects are analyzed to measure the level of motivation of farmers in implementing the GAP of Arabica coffee. The motivation of farmers in implementing GAP of the Arabica coffee commodity on each indicator, among others:

The Need for Existence

Existence needs is a need to maintain the existence of the farmer in his life. The need for existence (existence needs) is measured to see the level of encouragement of farmers in implementing good Agriculture Practices of Arabica commodities. The results of the scores on this indicator are presented in Table 3.

\begin{tabular}{lccc}
\hline \multicolumn{1}{c}{ Existence Indicator } & Score Interval & Mean Score & Level of Existence Indicator (\%) \\
\hline the needs of the householdeconomy aremet & $1-5$ & 4,38 & 87,70 \\
the desire to increase the productivity of the & $1-5$ & 4,03 & 86,00 \\
Arabica coffee crop & & & \\
the desire for thenecessities oflife is more secure & $1-5$ & 4,17 & 83,30 \\
The desire for Arabica coffee faming is better in & $1-5$ & 3,85 & 77,00 \\
tems of land use and the best quality of Arabica & & & \\
coffee beans & & & \\
the desire to do faming thatpreserves nature & $1-5$ & 4,00 & 80,00 \\
The desire for increasing family income & $1-5$ & 4,47 & 89,30 \\
$\quad$ Total & $1-30$ & 25,16 & 83,88
\end{tabular}

- $129,50 \quad$ Source Pu Primary Data, 2019

187,00 shows that 25,00 level of 26,00

Tab25. 30 shows that the devel of farmer motivation on the indicator of the need for existences $5,2,3$ in the high category, which-is 83.88 percen 6 , The majority $y_{3}$ of 8 offee farmers apply good agriculture practice to the Arabica coffee commodity to meet their existence needs because they want to increase family income (89.30 percent).

The need to relate to other people (relatedness needs) emphasizes the importance of relationships between interpersonal relationships and social relationships. Relatedness needs are measured to see the extent to which relatedness needs can encourage farmers to implement good agriculture practice of the Arabica coffee commodity that has been provided through agricultural extension activities. The scores for this indicator are presented in Table 4.

Table 4. Motivation Level of Farmers in Implementing Good Agriculture Practices of Arabica Coffee on the Relatedness Indicator

\begin{tabular}{|c|c|c|c|}
\hline Relatedness Indicator's & $\begin{array}{l}\text { Interval } \\
\text { Score }\end{array}$ & $\begin{array}{l}\text { Mean } \\
\text { Score }\end{array}$ & $\begin{array}{l}\text { Level of Relatedness } \\
\text { Indicator }(\%)\end{array}$ \\
\hline want information for applying the GAP of Arabica Coffee & $\overline{1-5}$ & 3,37 & 67,30 \\
\hline want to make lots of friends with other Arabica coffee farmers & $1-5$ & 3,30 & 66,00 \\
\hline want close to PPL & $1-5$ & 3,22 & 64,30 \\
\hline want to follow every activity camied out in the environment & $1-5$ & 3,35 & 67,00 \\
\hline Total & $1-20$ & 13,23 & 66,16 \\
\hline
\end{tabular}

Source: Primary Data, 2019

Table 4 shows that the level of motivation of farmers on the indicators of the need for relatedness is high, which is 66.16 percent. The majority of coffee farmers apply good agriculture practice to the Arabica coffee commodity to meet the needs of relatedness because they want information about applying good agriculture practice to the Arabica coffee commodity (67.30 percent). This is also supported by the high desire of farmers to participate in every activity carried out in the surrounding environment (67.00 percent). Self-development needs (growth needs) are measured to see the level of encouragement of farmers in implementing good agriculture practice of Arabica coffee commodities that have been provided through agricultural extension activities. The scores for this indicator are presented in Table 5. 
Table 5. Motivation Level of Farmers in Implementing Good Agriculture Practices of Arabica Coffee on Growth Indicators coffee farmers are motivated to apply the GAP of Arabica coffee commodity in South Tapanuli Regency.

Growth Indicators
want to improve skills in the practice of applying GAP of Arabica Coffee
want to improve skills about harvesting procedures according to Arabica
coffee ngin meningkatkan keterampilan tentang tata cara panen
want to improve skills in handling post-harvest
want to be proficient in cultivating environmentally friendly Arabika
coffee
want to increase knowledge about coffee plants and willingness to be
creative to develop trials of their findings
want to get a wider Arabica coffee farming business information network
want to increase the income of Arabica coffee farming
Total

\section{Source: Primary Data, 2019}

Table 5 shows that the level of motivation of farmers on the indicator of self-development needs (growth) is high $(54,69$ percent). The high motivation of farmers to meet the needs for self-development (growth) is because of the desire of Arabica coffee farming and to increase of Arabica coffee farming simultaneously $(60,20$ percent $)$.

The result of the measurement of the three aspects of farmer's motivation in adopting innovations in implementing GAP of Arabica coffee in the research location is detailed in the following table.

Table 6. The Motivation Level of Farmers in Applying GAP of Arabica coffee commodity

\begin{tabular}{|c|c|c|c|}
\hline Motivation Aspects & $\begin{array}{c}\text { Interval } \\
\text { Score }\end{array}$ & $\begin{array}{l}\text { Mean } \\
\text { Score }\end{array}$ & $\begin{array}{c}\text { Level of } \\
\text { Motivation (\%) }\end{array}$ \\
\hline existence & $1-30$ & 25,16 & 83,88 \\
\hline relatedness & $1-20$ & 13,23 & 66,16 \\
\hline growth & $1-35$ & 26,80 & 54,69 \\
\hline Total & $0-85$ & 65,19 & 68,24 \\
\hline
\end{tabular}

Table 6 shows that the level of motivation of the farmers as a whole is high $(68,24$ percent). The highest motivation aspect of farmers is the indicator of existence. The high percentage of farmer motivation to neet existence is related to the desire to increase family income.

The result of the measurement of the level of motivation of farmers in implementing GAP of Arabica coffee is described in Table 7.

Table 7. Distribution of Farmer Motivation Categories in Implementing GAP of Arabica Coffee Commodity

\begin{tabular}{ccc}
\hline Categories & Interval Score & Total $(\%)$ \\
\hline Low & $<21,73$ & 48,33 \\
High & $>21,73$ & 51,66 \\
Total & & 100
\end{tabular}

Source: Primary Data, 2019

Overall, the motivation level of farmers in applying GAP of Arabica coffee commodity is shown in Table 7, which is in the high category $(51,66)$. The high level of motivation of coffee farmers in implementing GAP of Arabica coffee because farmers want to increase family income. This is because the price of speciality Arabica coffee has a relatively high selling value in the global market. Therefore,

\section{Interval Score Mean Score Indicators (\%)}

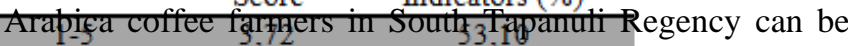
seen-based on age,6education, experience in farming coffee, income generation, the land area managed for the cultivation of 1 Afabica coffee commodity.1, $\bar{E}$ Each of theses farmer

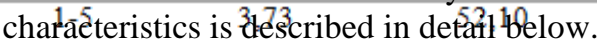

\begin{tabular}{|c|c|}
\hline Age $^{1-5}$ f Farmers ${ }^{4,22}$ & 53,30 \\
\hline 4,22 & 60,20 \\
\hline
\end{tabular}

The age composition of coffee farmers is categorized into twd-broad categories according tto the mean value, namely the young age group ( $<43$ years) and the old group $(>43$ years). Based on the measurement results, it is known that the age composition of the farmers in the study location is detailed in Table 8.

Table 8. Distribution of Farmers by Age

\begin{tabular}{ccc}
\hline Ages & Total (person) & $\%$ \\
\hline Young $(<43$ years) & 24 & 40 \\
Old ( $>43$ years) & 36 & 60 \\
Total & 60 & 100
\end{tabular}

Source: Primary Data, 2019

Table 8 shows that most coffee farmers are in the old age group category $(60,00$ percent). Farmers in the young age group have a faster learning capacity than older people. This can influence individuals in making decisions to adopt innovations to implement GAP of Arabica Coffee commodity. According to Soekartawi (2005) states that the younger the farmer has a higher enthusiasm and curiosity so that the adoption of innovation is faster. Age can also be related to the experience of farmers in managing their farms. Furthermore, Nurhardjo (2012) stated that the higher the working age, the better of performance. This is because the level of expertise and skills possessed is influenced by the experience gained while working.

\section{Education}

For a long time, farmers have attended formal education that has been attended by farmers, starting from elementary schools, junior high schools, high school, and tertiary education levels. The education composition of coffee farmers is categorized into two broad categories according to the mean value, namely the low education group $(<12$ years) and the higher education group ( $>12$ years). Based on the measurement results, it is known that the age composition of the farmers in the study location is detailed in Table 9.

Table 9. Distribution of Farmer by Education

\begin{tabular}{ccc}
\hline Education (years) & Total (person) & $\%$ \\
\hline Low $(<12$ years) & 17 & 28 \\
High $(>12$ tahun $)$ & 43 & 72 \\
Total & 60 & 100
\end{tabular}

Source: Primary Data, 2019 
Based on Table 9, shows that the education level of the dominant farmers is in the high category $(72,00$ percent) who attended formal education for more than 12 years. The high level of education for farmers is dominated by high school graduates (SMA/ SMK). Farmers with the lowest education category only took 6 years of elementary school education, and the highest education category was high education as a Bachelor (S1). The high level of farmer education can support the process of receiving information and technology that is passed on to farmers. Based on the theory of self-categorization (self-categorization) put forward by Turner (1985) in Sarwono (2005), categorization theory puts pressure on cognitive factors in social identity theory. The level of education is one part of one's social identity in social life. A person who has higher education tends to be prominent, full of confidence, and easy to adapt to new things around him. In this study, the majority of farmers were in the category of higher education, meaning that their ability to accept renewal would more easily be included in their farming activities. The level of education affects a person's actions and behaviour in considering rationally and receiving information, especially for decision making to adopt a new technological innovation (Suryani et al., 2017).

\section{Experience}

The farming experiences that have been passed by these farmers in this study are divided into two categories, namely new and old. The classification of these categories is determined based on the length of farming experience by the farmer. The results of measurements about the experiences of farmers in the study locations are described in detail in Table 10.

Table 10. Distribution of Farmers by Experience

\begin{tabular}{ccc}
\hline Experience $($ years $)$ & Total $($ person $)$ & $\%$ \\
\hline High $(>4,16$ years $)$ & 25 & 42 \\
Low $(<4,16$ years $)$ & 35 & 58 \\
Total & 40 & 100
\end{tabular}

Source: Primary Data, 2019

Table 10 shows that the majority of farmers have low experience in coffee commodity cultivation, namely 58.00 percent of coffee farmers. The farming experience factor is related to how farmers make various efforts to increase their agricultural productivity. According to Sajogwo and Pudjiwati (2013), the experience is the knowledge that a person experiences in an indefinite time. An experienced farmer tends to be more confident in managing the commodity cultivation business. Meanwhile, farmers who have just had experience tend to be at the stage of trying to manage and develop based on their information and knowledge.

The experience of farmers in managing their business can affect the mental attitude of acceptance of innovation, especially related to their interest and motivation to try something new that will have an impact on the success or failure they receive. The low level of experience in cultivating coffee has affected farmers' efforts to do new things, such as adopting good cultivation of Arabica coffee. The farmer's income level is calculated from the farm income managed by the farmer concerned. Farmers' income levels are categorized based on the amount of farmer income for one year which is calculated in Rupiah (Rp.). The income level of the farmers is divided into two categories, namely low and high income. The composition of farmers' income in the study location is shown in Table 11.

Table 11. Distribution of Farmers by Income Level

\begin{tabular}{ccc}
\hline Income (Rp.) & Total (person) & $\%$ \\
\hline High (>Rp. 2.240.000) & 27 & 45 \\
Low (<Rp. 2.240.000) & 33 & 55 \\
Total & 60 & 100
\end{tabular}

Source: Primary Data, 2019

Table 11 shows that the majority of farmers fall into the low-income category. The farmer who has the lowest income is less than Rp. 2,240,000,- / month by 55.00 percent. The farmer who has the lowest income is $\mathrm{Rp}$. $1,100,000,-$ / month. The income level of farmers affects farmers' efforts to make innovations in the development of the farms they manage. According to Kartasapoetra (1994), farmers who have high incomes tend to be more active and can seek various information and knowledge related to updates in the farming business they manage. These farmers are classified as innovators or pioneer farmers because they have a strong desire to succeed and increase their farming. Meanwhile, in this study, the majority of farmers fall into the low-income category so that it has an impact on their low willingness and ability to change behaviour, especially in making decisions to apply good cultivation to the Arabica coffee commodity.

\section{Land Area}

Farmer's land area is divided into two categories, namely narrow land, and wide land. The classification of these categories is determined based on the area of land managed by the farmer. The results of the measurement of the composition of the land area of farmers in the study location can be seen in Table 12 .

Table 12. Distribution of Farmers by Land Area

\begin{tabular}{ccc}
\hline Land Area & Total (person) & $\%$ \\
\hline Narrow land $(>0,81 \mathrm{Ha})$ & 24 & 40 \\
Wide land $(<0,81 \mathrm{Ha})$ & 36 & 60 \\
Total & 60 & 100
\end{tabular}

Source: Primary Data, 2019

Based on Table 12, it can be seen that most of the farmers are categorized as farmers with narrow land, namely 60.00 percent. Farmers have a narrow land category island smaller than $0.81 \mathrm{Ha}$, while the broad category island large than $0.81 \mathrm{Ha}$. Farmers with the narrowest land use were $0.25 \mathrm{Ha}$, while farmers with the widest land use were $2 \mathrm{Ha}$.

Land ownership is an important capital in starting an agricultural business. To determine the area of land that is managed, it affects farm financing, which is issued as the input cost of farm production. Farmers who have a narrow 
land area so that farmers always act and are more careful because they are afraid of experiencing failure as a result of the application of cultivation carried out on that land. Farmers in this case will follow and implement technological updates if most of the farmers around their environment have implemented and see good results from the changes they have made. As a result, the application of innovation for the category of farmers with a narrow land area is slow (Kartasapoetra, 1994).

\section{External Factors of Farmers}

The nature of innovation in applying good cultivation to the Arabica coffee commodity in the study is seen based on the opinion of farmers on the innovation itself, both intrinsic and extrinsic characteristics of implementing good cultivation on Arabica coffee commodities. The results of the measurement of farmers' assessments of the nature of innovation in applying good cultivation to the Arabica coffee commodity are described in the following table.

Table 13. The nature of innovation in implementing good cultivation of Arabica coffee commodities according to farmers social and cultural values of the people in the South Tapanuli Regency (77.00 percent).

\section{Results of Analysis of Factors Affecting the Motivation of Coffee Farmers in implementing good cultivation of coffee in the South Tapanuli Regency}

In this study, the factors that are thought to influence the motivation of implementing good cultivation of Arabica coffee by farmers are divided into two groups, namely the internal factors of farmers and external factors of farmers. Internal factors consisting of: age, education, experience, income, and land area. External factors include the nature of innovation. The second objective hypothesis is, it is assumed that age (X1), education (X2), income (X3), experience (X4), land area (X5), and the nature of innovation (X6) have a significant effect on the motivation level of coffee farmers in applying cultivation. which is good for arabica coffee commodity in South Tapanuli Regency. The following are the results of the analysis in Table 14.

Table 14. Analysis of factors that affect the level of motivation of coffee farmers in implementing good

\begin{tabular}{|c|c|c|}
\hline Innovation Nature GAP of Arabica Coffee & 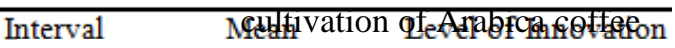 & \\
\hline & Y (Motivation) & Reg Result \\
\hline $\begin{array}{l}\text { The innovation of implementing good cultivation on the Arabica } \\
\text { coffee commodity is easy to inform the famers }\end{array}$ & $\mathrm{X} 1$ (Age) & $\begin{array}{c}-0.176^{* * *} \\
(0.0657)\end{array}$ \\
\hline $\begin{array}{l}\text { Innovation in applying good cultivation to the Arabica coffee } \\
\text { commodity is easy to work on technically }\end{array}$ & $\mathrm{X} 2$ (Education) & $\begin{array}{c}0.360 \\
(0.233)\end{array}$ \\
\hline $\begin{array}{l}\text { Innovation in applying good cultivation to the Arabica coffee } \\
\text { commodity is more efficient (economical) } \\
\text { Innovation in implementing good cultivation of the Arabica coffee }\end{array}$ & $\mathrm{X} 3$ (Income) & $\begin{array}{c}1.31 \mathrm{e}-06 \\
(1.03 \mathrm{e}-06)\end{array}$ \\
\hline $\begin{array}{l}\text { commodity is in accordance (not in conflict) with the social and } \\
\text { cultural values of the community }\end{array}$ & $\mathrm{X} 4$ (Experience) & $\begin{array}{c}1.179 * * * \\
(0.311)\end{array}$ \\
\hline $\begin{array}{l}\text { Innovation in implementing GAP of Arabica coffee commodity is } \\
\text { following agricultural development policies (plantation) in North }\end{array}$ & X5 (Land Area) & $\begin{array}{l}-1.507 \\
(1.124)\end{array}$ \\
\hline $\begin{array}{l}\text { Sumatera } \\
\text { Innovation in applying GAP of Arabica coffee commodity is easy to }\end{array}$ & X6 (Innovation nature) & $\begin{array}{l}0.328^{*} \\
(0.183)\end{array}$ \\
\hline observe & Constant & $48.97^{* * *}$ \\
\hline $\begin{array}{l}\text { Innovation in implementing good cultivation of the Arabica coffee } \\
\text { commodity is suitable for geooraphical conditions and local }\end{array}$ & & $(10.03)$ \\
\hline $\begin{array}{l}\text { environmental climatic conditions } \\
\text { Innovation in implementing good cultivation of Arabica coffee }\end{array}$ & Observations & 60 \\
\hline $\begin{array}{l}\text { Innovation in implementing good cultivation of Arabica coffee } \\
\text { commodities can adapt to changes in weather and extreme climate }\end{array}$ & R-squared & 0.335 \\
\hline
\end{tabular}

The innovation of applying good cultivation to the Arabica coffee commodity can overcome the problems of the quality and economic

yield of Arabica coffee by farmers

The innovation of implementing good cultivation of Arabica coffee commodities can be applied in a sustainable manner

$$
\text { Total }
$$

Source: Primary Data, 2019

\section{Source: Primary Data, 2019}

Based on the resula th of the regress above, it shows that simultaneously the variables X1 (age), $x_{4}^{1}$ (experiences), and X6 (nature of innovation) affect the motivation level, of coffee farmers in implementing good cultivation of Arabica coffee. The age variable is stated to have a negative effect with the direction of the negative regression coefficient $(-0.176)$, meaning that the older the farmer is, the lower the motivation level or the younger the farmer is, the higher the level of motivation in applying good cultivation to the Arabica coffee commodity. The experience variable is stated to have a positive effect with the direction of the positive regression coefficient (1.179), meaning that the higher the experience of the farmer, the higher the motivation level, or the lower the experience of the farmer, the lower the motivation level in implementing good cultivation of Arabica coffee.

The variable X6 (the nature of innovation) which is the external factor of farmers has a positive effect on the 
direction of the positive regression coefficient (0.328). This means that the easier and more cost-effective it is to implement these innovations, the higher the motivation level of coffee farmers in implementing good cultivation of Arabica coffee. Meanwhile, for the variables X2 (education), X3 (income), and X5 (land area) did not have a significant effect on the motivation level of coffee farmers in implementing good cultivation of Arabica coffee.

\section{Conclusion}

South Tapanuli Regency (Kabupaten Tapanuli Selatan) with its natural geographical conditions, has the potential for natural resources in agriculture, currently coffee is a famous plant among the farming community. An increase in Arabica coffee production can be achieved with an intensification strategy through optimizing land use and family labor used as well as implementing good Agriculture Practices of commodities. However, it is also necessary to pay attention to the socio-economic and ecological conditions faced by farmers to promote sustainable growth that is towards standards oriented.

The motivation level of farmers in applying GAP of Arabica coffee commodity is in the high category $(51,66)$. The high level of motivation of coffee farmers in implementing GAP of Arabica coffee-related the Arabica coffee has a relatively high selling value in the global market. The factors that are influencing the motivation of implementing good cultivation of Arabica coffee by farmers are age, experience, innovation. While, education, income, and the land area did not have a significant effect on the motivation level of coffee farmers in implementing good cultivation of Arabica coffee

\section{References}

[1] Agam, S. (2018). Surga Kopi Arabika di Sumatera Utara. Retrieved from http://indonesiabaik.id/infografis/kopisumaterautara

[2] Amanah, S., \&amp; Tjitropranoto, P. (2018). Tingkat Adopsi Good Agricultural Practices Budidaya Kopi Arabika Gayo oleh Petani di Kabupaten Aceh Tengah. Tingkat Adopsi Good Agricultural Practices Budidaya Kopi Arabika Gayo Oleh Petani Di Kabupaten Aceh Tengah, 14(2).

https://doi.org/10.25015/penyuluhan.v14i2 .1975712

[3] Badan Pusat Statistik. (2017). No Title. Provinsi Sumatera Utara. Retrieved from https://sumut.bps.go.id/statictable/2017/10 /11/666/luas-komoditi-dan-produksi-kopiarabika-komoditi-perkebunan-rakyatmenurut-kabupaten-kota-2015.html
[4] Barnas, S., \&amp; Ridwan, I. M. (2019). Perbedaan Gender dalam Pengetahuan, Sikap dan Perilaku Mahasiswa Pendidikan Fisika, 1(2), 34-41.

[5] Bogor, I. P. (2017). Peran Komoditas Kopi Bagi Perekonomian Indonesia. Retrieved from http://sustainability.ipb.ac.id/wpcontent/uploads/2019/01/13.Peran-

Komoditas-Kopi-Bagi-PerekonomianIndonesia.Pdf

[6] Budiman, H. (2014). Prospek Tinggi Bertanam Kopi; Pedoman Meningkatkan Kualitas Perkebunan Kopi. (Flo, Ed.) (Cetakan Pertama). Yogyakarta: Pustaka Baru Press.

[7] Kartasapoetra, A. G. (1994). Teknologi Penyuluhan Pertanian (Keempat). Jakarta: Bumi Aksara.

[8] Mardikanto, T. (n.d.). Sistem Penyuluhan Pertanian. Surakarta: Universitas Sebelas Maret Press.

[9] Nurhardjo, B. (2012). Karakteristik dan Kinerja Buruh Wanita pada Gudang Tembakau Gmit di

[10] Kecamatan Panti Kabupaten Jember. Bisma Jurnal Bisnis Dan Manajemen, 6(1), 55-68.

[11] Panggabean, E. (2019). Buku Pintar Kopi. (P. U. Opi Noviandi, Ed.) (Kedua). Jakarta: PT. Agromedia Pustaka.

[12] Perkebunan, D. (2019). Pembangunan Sumatera Utara Tahun 2019. Retrieved February 1, 2019, from http://disbun.sumutprov.go.id/wpcontent/uploads/RDP-FEBRUARI-2019tanpa-foto-produk-1-FINAL-1.pdf

[13] Perkebunan, D. J. (2019). Pengembangan Kopi Nasional Antisipasi Dampak Perubahan Iklim. Retrieved from http://tanhun.ditjenbun.pertanian.go.id/we b/page/title/116/pengembangan-kopinasional-antisipasi-dampak-perubahaniklim?post_type=informasi

[14] Ratnasari, D. E. (2018). Mengenal Lebih Dekat Rasa Kopi Spesialti. Retrieved from https://www.antaranews.com/berita/72052 
0/indonesia-dorong-ekspor-kopispeciality-ke-eropa

[15] Sumarno, J., Sari, F., \&amp; Hiola, I. (2017). Socio-Economic Factors Affecting Farmers Adopting Innovation of Integrated Crop Management of Maize in Gorontalo. Informatika Pertanian.

[16] Sajogyo, P. (2013). Sosiologi Pedesaan Jilid II. (P. S. Sajogyo, Ed.) (Jilid II). Yogyakarta: Gadjah Mada University Press.

[17] Sarwono, S. W. (2005). Psikologi Sosial; Psikologi Kelompok dan Psikologi Terapan. Jakarta: Balai Pustaka.

[18] Sudarko. (2012). Tingkat Kemampuan Anggota Kelompok Tani Dalam Penerapan Teknologi usahatani Kopi Rakyat. Jurnal Sosial Ekonomi Pertanian, 6 (1), 1-11. Retrieved from https://jurnal.unej.ac.id/index.php/JSEP/art icle/view/798/614

[19] Sudjarmoko, B. (2013). Prospek Pengembangan Industrialisasi Kopi Indonesia. Sirinov, 1(3), 99-110.

[20] Rahma, S. (2017). Indonesia Produsen Kopi Terbesar Keempat Di Dunia. Www.Cnnindonesia.Com. Retrieved from https://www.cnnindonesia.com/gayahidup/20180426212944-262293962/mengenal-lebih-dekat-rasa-kopispesialti

[21] Sustainable Coffee Paltform Indonesia. (2017). Kurikulum Nasional dan Modul Pelatihan Budidaya Berkelanjutan Good Agricultural Practices dan Pasca Panen (Post Harvest) Kopi Arabika. Retrieved from https://scopi.or.id/wpcontent/uploads/2018/09/NSC-Arabika- 